\title{
Long-term results of coronary surgery with endoscopic vein harvesting
}

\author{
Endoskopik ven hazırlama ile koroner cerrahinin uzun dönem sonuçları

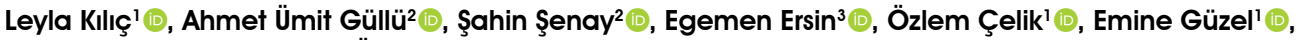 \\ Neriman Özge Çalışkan' ${ }^{(1)}$, Muharrem Koçyiğit ${ }^{4}$ (D) Cem Alhan² ${ }^{(D)}$ \\ Institution where the research was done: \\ Acıbadem Mehmet Ali Aydınlar University, School of Medicine, Istanbul, Turkey \\ 'Department of Nursing, Acıbadem Mehmet Ali Aydınlar University, Faculty of Health Sciences, Istanbul, Turkey \\ 2Department of Cardiovascular Surgery, Acıbadem Mehmet Ali Aydınlar University, School of Medicine, Istanbul, Turkey \\ ${ }^{3}$ Department of Perfusion, Acibadem Mehmet Ali Aydinlar University, Institute of Health Sciences, Istanbul, Turkey \\ ${ }^{4}$ Department of Anesthesiology and Reanimation, Acıbadem Mehmet Ali Aydınlar University, School of Medicine, Istanbul, Turkey
}

\begin{abstract}
Background: In this study, we aimed to evaluate early and longterm outcomes of both isolated or concomitant coronary artery bypass grafting with the endoscopic vein harvesting technique.

Methods: Between November 2012 and May 2017, a total of 324 patients (259 males, 65 females; mean age: $63.2 \pm 9.8$ years; range, 36 to 91 years) who underwent coronary artery bypass grafting, with or without concomitant procedures, using the endoscopic vein harvesting technique were retrospectively analyzed. Early postoperative outcomes and long-term follow-up data of the patients, such as cardiovascular or cerebral events, cardiac reinterventions, and the images of coronary angiography were recorded.

Results: Median logistic EuroSCORE and in hospital mortality was $3.99(0.8-81) \quad v s .0 .9 \%$ for isolated coronary surgery and 13.34 (1.5-76.4) vs. $1.5 \%$ for concomitant procedures. The long-term data could be obtained in 288 patients with a median of 59.6 (7-90) months of follow-up. During this period, $22(7.6 \%)$ patients underwent coronary angiography for control or treatment, $12(4.2 \%)$ patients needed revascularization, and none of the patients underwent redo coronary surgery.
\end{abstract}

Conclusion: Our study results suggest that the endoscopic vein harvesting technique during coronary artery bypass grafting is safe in experienced hands.

Keywords: Coronary artery bypass grafting, endoscopic vein harvesting, graft patency.

\section{$\ddot{O} Z$}

Amaç: Bu çalışmada, endoskopik ven hazırlama tekniği ile izole veya eş zamanlı koroner arter baypas greftlemenin erken ve uzun dönem sonuçları değerlendirildi.

Çalışma planı: Kasım 2012 - Mayıs 2017 tarihleri arasında eş zamanlı işlemler ile birlikte veya tek başına, endoskopik ven hazırlama tekniği kullanılarak koroner arter baypas greftleme yapılan toplam 324 hasta (259 erkek, 65 kadın; ort. yaş: $63.2 \pm 9.8$ yıl; dağılım 36-91 y1l) retrospektif olarak incelendi. Kardiyovasküler veya serebral olaylar, kardiyak girişimler ve koroner anjiyografi görüntüleri dahil olmak üzere hastaların ameliyat sonrası erken dönem sonuçları ve uzun dönem takip verileri kaydedildi.

Bulgular: İzole koroner cerrahi hastalarında ortalama lojistik EuroSCORE 3.99 (0.8-81) iken mortalite oranı \%0.9; eşlik eden cerrahi prosedür varlığında ise ortalama lojistik EuroSCORE 13.34 (1.5-76.4) iken mortalite oran1 \%1.5'tir. Uzun dönem veriler 288 hastanın ortalama 59.6 ay (7-90) boyunca takip edilmesi sonucu elde edildi. Bu süre zarfında 22 hastaya (\%7.6) kontrol veya tedavi için koroner anjiyografi yapıldı, 12 hastada (\%4.2) revaskülarizasyon gereksinimi oldu ve hastaların hiçbirine yeniden koroner cerrahi yapılmadi.

Sonuç: Çalışma sonuçlarımız koroner arter baypas greftleme sırasında endoskopik ven hazırlama tekniğinin deneyimli ellerde güvenli olduğunu göstermektedir.

Anahtar sözcükler: Koroner arter baypas greftleme, endoskopik ven hazırlama, greft açıklı̆̆ı.

Received: March 21, 2021 Accepted: September 27, 2021 Published online: October 20, 2021

Correspondence: Egemen Ersin. Acıbadem Maslak Hastanesi, Kalp ve Damar Cerrahisi Kliniği, 34457 Sarıyer, İstanbul, Türkiye. Tel: +90 538 - 5752666 e-mail: egemn.ersin@gmail.com 
Harvesting of the great saphenous vein with the conventional open technique involves a long skin incision, which carries a high incidence of wound complications, and pain during coronary artery bypass grafting $(\mathrm{CABG}){ }^{[1]}$ Additionally, open technique often leads to the increased length of hospital stay and a decrease in patient satisfaction. To reduce the morbidity of this procedure, a technique of endoscopic vein harvesting $(\mathrm{EVH})$ was adopted to $\mathrm{CABG}$ recently. The EVH allows long segment harvest of the saphenous vein, with high-quality visualization, through a minimal incision. However, due to the potential implications of the early and long-term impact on outcomes, the role of EVH is currently the subject of much controversy in the literature..$^{[2-5]}$

In the present study, we aimed to evaluate the long-term outcomes of both isolated or concomitant CABG with the EVH technique and to investigate all cardiovascular and cerebral events, echocardiographic measurements, mortality, and the images of patients requiring coronary angiography during follow-up.

\section{PATIENTS AND METHODS}

This single-center, retrospective study was conducted at Acıbadem Maslak Hospital, Department of Cardiovascular Surgery between November 2012 and May 2017. A total of 324 patients (259 males, 65 females; mean age: $63.2 \pm 9.8$ years; range, 36 to 91 years) who underwent CABG, with or without concomitant procedures, using EVH technique were included. Data including medical histories, demographic characteristics, comorbidities, operative and laboratory results, electrocardiography findings, wound-related complications, and early postoperative outcomes were retrieved from the hospital database. Data for long-term follow-up, such as cardiovascular or cerebral events, cardiac reinterventions (percutaneous coronary intervention [PCI] or redo $\mathrm{CABG}$ ), echocardiographic measures, and the images of coronary angiography were obtained from hospital database or via phone call and/or e-mail. Patients less than six months of follow-up or who could not be contacted following the operation were excluded from the study $(n=36)$. A written informed consent was obtained from each patient. The study protocol was approved by Institutional Review Board on 18.01.2021. The study was conducted in accordance with the principles of the Declaration of Helsinki.

Endoscopic saphenous vein harvesting technique, which was previously detailed, ${ }^{[6]}$ was performed by a single surgeon in all patients. Two types of systems were used according to the operator preference: VirtuoSaph ${ }^{\circledR}$ (Terumo Europe, Leuven, Belgium) or Vasoview ${ }^{\circledR}$ (Maquet GmbH, Germany). The figures of incisions during endoscopic and open vein harvesting are presented in Figure 1a, b. The application of EVH during surgery and the saphenous vein removed via EVH is also shown in Figure 2a, $b$.

All patients underwent CABG with cardiopulmonary bypass in a usual fashion, and off-pump procedures were excluded from the study. Hypothermic total circulatory arrest $\left(18^{\circ} \mathrm{C}\right)$ was performed in the patients who underwent aortic arch or hemiarch aortic replacement concomitant with CABG (1.2\%).
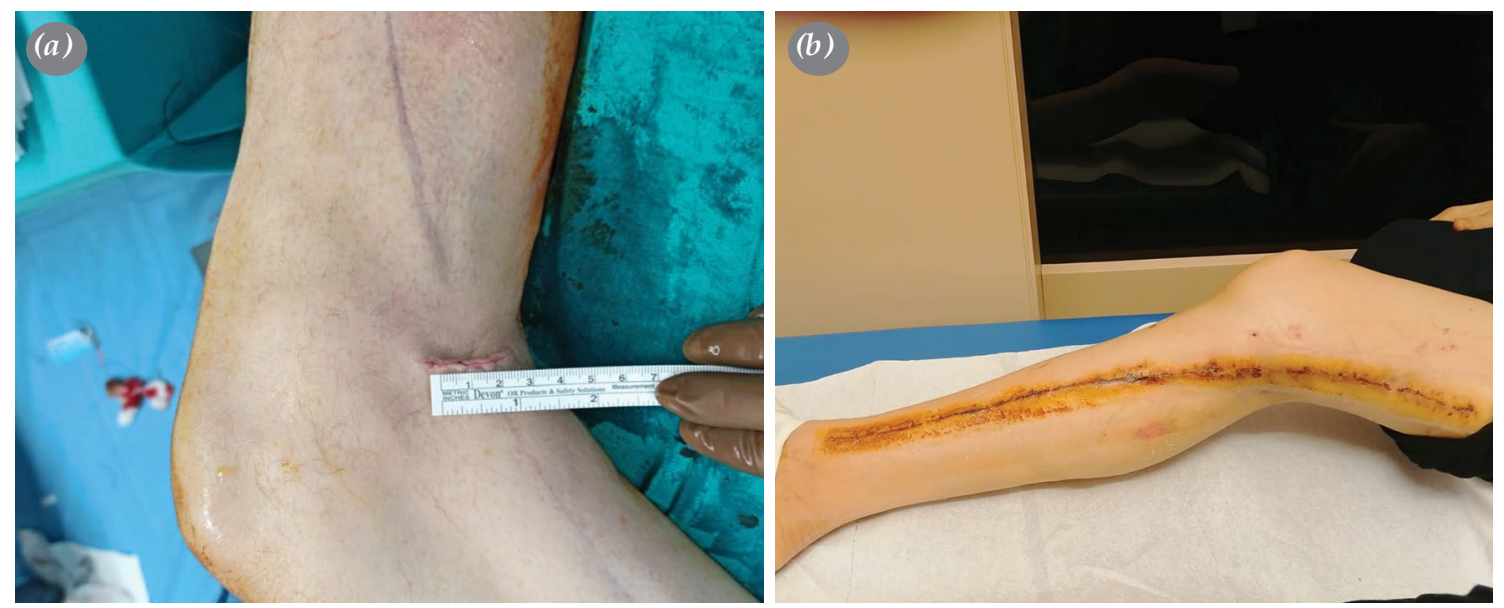

Figure 1. (a) Incision for endoscopic vein harvesting. (b) Incision during open vein harvesting. 


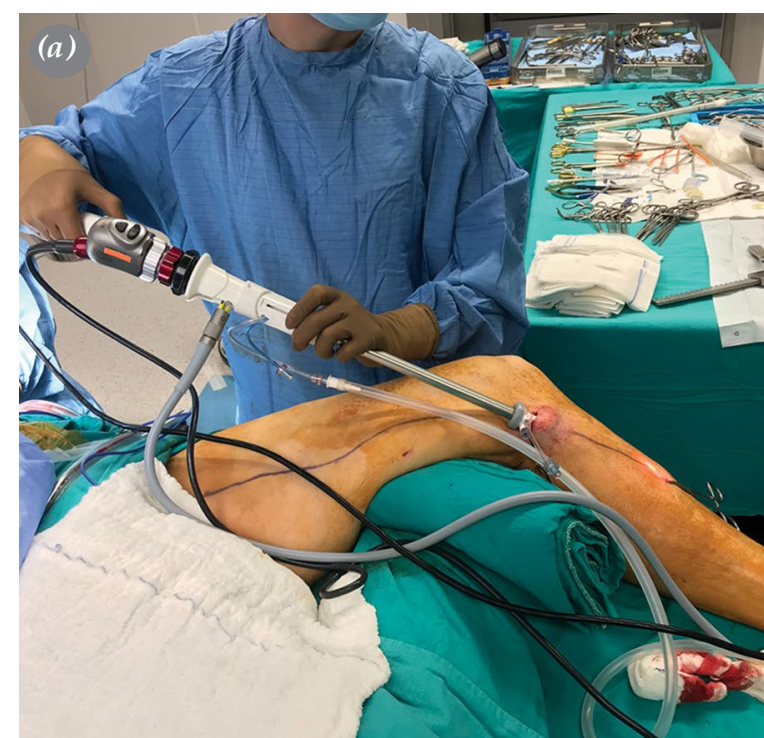

Figure 2. (a) Application of endoscopic vein harvesting. harvesting.

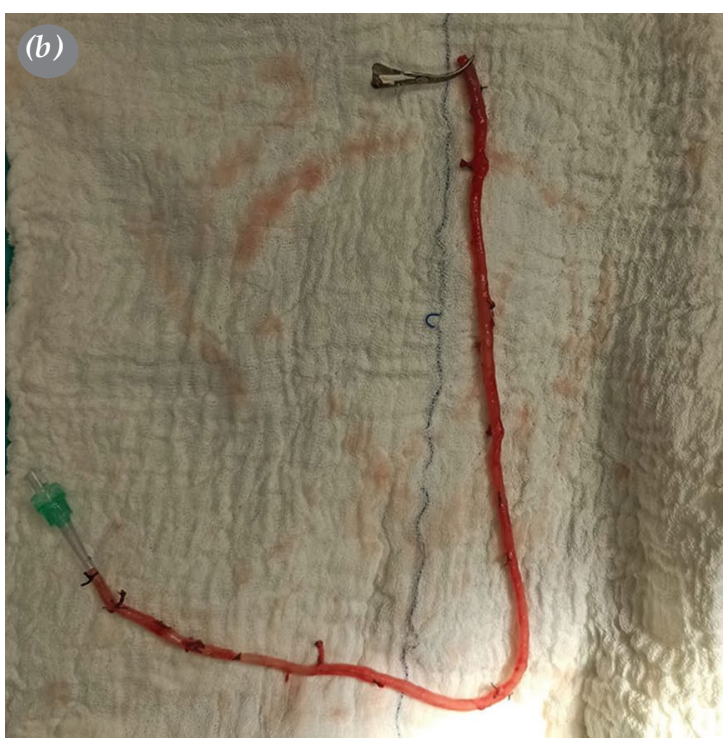

(b) Saphenous vein graft removed by endoscopic vein

\section{Statistical analysis}

Statistical analysis was performed using the SPSS version 18.0 software (SPSS Inc., Chicago, IL, USA). Descriptive data were expressed in mean \pm standard deviation (SD), median (min-max), or number and frequency. Descriptive statistics were used to summarize the set of observations. A $p$ value of $<0.05$ was considered statistically significant.

\section{RESULTS}

During the study period, a total of 247 (76.3\%) and $77(23.7 \%)$ patients underwent isolated CABG and concomitant procedures using EVH, respectively. The median logistic EuroSCORE and in-hospital mortality was $3.99(0.8-81)$ vs. 13.34 (1.5-76.4) and $3(0.9 \%)$ vs. $5(1.5 \%)$ in patients for isolated CABG and concomitant procedures, respectively. Perioperative patient characteristics, the types of all operations, and postoperative complications are presented in Tables 1-3.

In addition, EVH-related wound infection was observed in one $(0.3 \%)$ patient and seroma in another $(0.3 \%)$. Of all patients, the long-term data were obtained in 288 patients with a median of 59.6 (7-90) months.

Table 1. Perioperative data of patients $(n=324)$

\begin{tabular}{|c|c|c|c|c|}
\hline Demographics & $\mathrm{n}$ & $\%$ & Mean \pm SD & Min-Max \\
\hline Age & & & $63.2 \pm 9.8$ & $36-91$ \\
\hline Log EuroSCORE & & & $6.2 \pm 10.8$ & $0.9-81.6$ \\
\hline $\mathrm{EF}(\%)$ & & & $55.7 \pm 9.7$ & $20-70.1$ \\
\hline LVEDD (cm) & & & $4.9 \pm 0.5$ & $3.7-7.3$ \\
\hline CPB duration (min) & & & $100.9 \pm 32.6$ & $37-254$ \\
\hline ICU stay (h) & & & $34 \pm 36.2$ & $12-138$ \\
\hline Number of grafts & & & $3.5 \pm 1.0$ & $1-7$ \\
\hline \multicolumn{5}{|l|}{ Sex } \\
\hline Female & 65 & 20.1 & & \\
\hline NYHA Class III-IV & 30 & 9.3 & & \\
\hline Type 2 DM (Insuline Dependent or not) & 144 & 44.4 & & \\
\hline
\end{tabular}


Table 2. Types of operation

\begin{tabular}{lcc}
\hline The procedure & $\mathrm{n}$ & $\%$ \\
\hline Isolated first time CABG & 247 & 76 \\
CABG + Mitral valve intervention & 20 & 6.2 \\
CABG + Mitral + Tricuspid valve intervention & 1 & 0.3 \\
CABG + Aortic valve replacement & 16 & 4.9 \\
CABG + Aortic replacement & 7 & 2.2 \\
CABG + Cryoablation + LAA closure & 9 & 2.8 \\
CABG + Mitral + Aortic replacement & 4 & 1.2 \\
CABG + LV aneurysmectomy & 2 & 0.6 \\
CABG + Mitral + Aortic valve replacement & 2 & 0.6 \\
CABG + Mitral + Tricuspid + Aortic valve replacement & 1 & 0.3 \\
CABG + Carotid endarterectomy & 3 & 0.9 \\
CABG + Aortic valve replacement + Aortic replacement & 3 & 0.9 \\
CABG + ASD closure & 1 & 0.3 \\
Redo CABG + Aortic valve + Aortic replacement & 2 & 0.6 \\
Redo CABG & 6 & 1.9 \\
\hline CABG: Coronary artery bypass grafting; LAA: Left atrial appendage; LV: Left ventricular; ASD: Atrial \\
septal defect. & &
\end{tabular}

During this period, 22 (7.6\%) patients underwent coronary angiography for control or treatment. The results of the coronary angiography are detailed in Table 4.

Postoperative coronary angiography $(n=22)$ showed that the all saphenous grafts were patent in 14 patients, and stenosis or occlusion in eight patients. Totally, $12(4.2 \%)$ patients of the patients during follow-up needed revascularization, PCI was performed in five patients for saphenous vein stenosis or occlusion and in seven patients for newly affected native coronary artery. None of the patients underwent re-CABG during this period.

Echocardiographic evaluation at 6 to 12 months following the operation revealed no significant difference in terms of the mean left ventricular end-diastolic diameter $(4.8 \pm 5.2 \mathrm{~mm})$, compared to baseline $(4.9 \pm 5.2 \mathrm{~mm})(\mathrm{p}=0.34)$ in patients who underwent isolated CABG. Similarly, ejection fraction values in the pre- and postoperative periods were similar (55.8\% vs. 55.9\%, respectively; $\mathrm{p}=0.87$ ). Major events during follow-up were coronary revascularization $(n=12,4.2 \%)$, stroke $(n=11,3.8 \%)$, malignancy $(\mathrm{n}=18,6.3 \%)$, and heart failure $(\mathrm{n}=7$, $2.4 \%$ ). In our cohort, the cause of death was defined as the disease or injury which started the sequence of morbid events, leading directly to death and there were nine deaths $(3.1 \%)$, related to cardiovascular reasons $(n=4,44.4 \%)$, malignancy $(n=3,33.3 \%)$, renal failure $(\mathrm{n}=1,11.1 \%)$, and stroke $(\mathrm{n}=1,11.1 \%)$ in the long-term follow-up.

Table 3. Early postoperative outcomes

\begin{tabular}{lcc}
\hline Complications & $\mathrm{n}$ & $\%$ \\
\hline Atrial fibrillation & 28 & 8.6 \\
Revision for bleeding & 3 & 0.9 \\
Pneumonia & 4 & 1.2 \\
Wound infection (sternal) & 4 & 1.2 \\
Revision for sternal dehiscence & 4 & 1.2 \\
Postoperative ECMO/IABP & 7 & 2.2 \\
Cerebrovascular accident & 7 & 2.2 \\
Pacemaker (permanent) & 1 & 0.3 \\
Post-pericardiotomy & 9 & 2.8 \\
In hospital mortality & 8 & 2.4 \\
$\quad$ Isolated CABG & 3 & 0.9 \\
$\quad$ Concomitant procedures & 5 & 1.5 \\
\hline ECMO: Extracorporeal membrane oxygenation; IABP: & Intra-aortic \\
balloon pump; CABG: Coronary artery bypass grafting. &
\end{tabular}


Table 4. Follow-up coronary angiography results $(n=22)$

\begin{tabular}{lll}
\hline & $\mathrm{n}$ & Explanation \\
\hline Patent saphenous vein (all) & 7 & $\begin{array}{l}\text { Control angiography revealed all grafts were patent } \\
\text { and no intervention was performed. }\end{array}$ \\
Patent saphenous vein-PCI for progressive coronary disease & 7 & $\begin{array}{l}\text { All grafts were patent. PCI applied to new diseased } \\
\text { and/or bypassed native vessel }\end{array}$ \\
$\begin{array}{l}\text { Saphenous vein occlusion-medical therapy } \\
\text { Saphenous vein occlusion-PCI for progressive coronary }\end{array}$ & 1 & $\begin{array}{l}\text { Saphenous veins were occluded, but PCI was not } \\
\text { suitable. }\end{array}$ \\
$\begin{array}{l}\text { disease } \\
\text { Saphenous vein stenosis-PCI to saphenous vein }\end{array}$ & 4 & \\
\hline
\end{tabular}

PCI: Percutaneous coronary intervention.

\section{DISCUSSION}

In the present study in which the saphenous vein was prepared with the EVH technique, used as a conduit during CABG operations, and followed for an average of five years were promising. Currently, in the practice of cardiac surgery, patients are more debilitated and interventions for accompanying cardiac diseases during CABG are performed more frequently. The feature that distinguishes our study from others is that it offers real-world experience in terms of longterm follow-up and consists of patients undergoing not only isolated CABG surgery, but also concomitant procedures. Coronary angiography was repeated after the previous operation in $7.6 \%(n=22)$ of the patients who were under follow-up, and revascularization by PCI was needed in only $4.2 \%$ of these patients.

The success of CABG operations depends on patency of the graft in the early or late period following operation, and it is of utmost importance that the graft is not damaged during harvesting. ${ }^{[7]}$ In randomized-controlled trials, there are concerns that the EVH technique may cause vascular damage, reducing the patency of the graft, increasing the risk of perioperative myocardial infarction, midand long-term angina, and mortality eventually. ${ }^{[6]}$ It has been shown how the ability and experience of the operator is vital during EVH. ${ }^{[7-10]}$ Therefore, a comprehensive learning plan should be made particularly in educational centers that would start the EVH program. As speculation, observation of better results in our study than other EVH studies can be associated with the operator experience. Both saphenous vein harvesting and $\mathrm{CABG}$ were performed by the single team from the beginning of the EVH program until the end of the study in our clinic.
Using the open saphenous vein harvesting technique, the incision is longer and the risk of contamination is higher in terms of infection. Another important advantage of EVH technique is that it significantly reduces complications related to wound site, particularly in patients with obesity and diabetes. ${ }^{[1]]}$ In a study investigating wound complications in patients with diabetes, $18.5 \%$ of the patients who had saphenous harvesting with the open technique had at least one problem such as infection, seroma, lymphocele, hematoma, cellulitis, edema, and infection with the wound site. ${ }^{[12]}$ In our study, $44.5 \%$ of patients were suffered from diabetes mellitus; however, seroma was observed in one of the patients $(0.3 \%)$, and infection requiring short-term antibiotic use was observed in another patient $(0.3 \%)$. Based on these findings, our study may support that EVH compared to open technique can be considered a cost-effective technique that reducing infection, use of antibiotics, length of hospital stay, and need for re-hospitalization. ${ }^{[13]}$

Nonetheless, this study has some limitations such as the presence of the patients who could not be followed $(n=36$ patients) and those possibly having cardiac or cerebral events in the long-term. The retrospective cohort design with prospectively collected data in a single center with the presence of concomitant cases may have also caused heterogeneity in the patient population, precluding a direct conclusion about the EVH technique. In addition, patients who were asymptomatic or did not undergo coronary angiography, but had occlusion or stenosis in the saphenous vein could not be shown in the study. Despite these limitations, we believe that our study reflects the real-world experience with the long-term data of the patients undergoing isolated or concomitant $\mathrm{CABG}$ 
with EVH technique. With the future technological investments of companies on this technique and the decrease in cost, this procedure may become routine in patients undergoing $\mathrm{CABG}$ using the saphenous vein.

In conclusion, our study results suggest that the endoscopic vein harvesting technique during coronary artery bypass grafting is safe in experienced hands. Further large-scale, prospective studies in the real-life setting are needed to gain a better understanding of this technique in this group of patients.

\section{Acknowledgements}

We would like to acknowledge our nurses Yagmur Bulbuller, Sevinc Kocaman, and Semih Aydemir for communicating with patients, collecting and recording data with complementary contributions for the present study.

\section{Declaration of conflicting interests}

The authors declared no conflicts of interest with respect to the authorship and/or publication of this article.

\section{Funding}

The authors received no financial support for the research and/or authorship of this article.

\section{REFERENCES}

1. Connolly MW, Poston RS. Endoscopic versus open veingraft harvesting. N Engl J Med 2009;361:1907-8.

2. Aranki SF, Shopnick B. Endoscopic versus open vein-graft harvesting. N Engl J Med 2009;361:1907.

3. Soni MK, Williams L, Raja SG. Use of endoscopic vein harvesting $(\mathrm{EVH})$ during coronary artery bypass grafting in United Kingdom: The EVH survey. Int J Surg 2019;69:146-51.

4. Harky A, Balmforth D, Shipolini A, Uppal R. Is endoscopic long saphenous vein harvesting equivalent to open harvesting technique in terms of graft patency? Interact Cardiovasc Thorac Surg 2017;25:323-6.

5. Zenati MA, Shroyer AL, Collins JF, Hattler B, Ota T, Almassi $\mathrm{GH}$, et al. Impact of endoscopic versus open saphenous vein harvest technique on late coronary artery bypass grafting patient outcomes in the ROOBY (Randomized On/Off Bypass) Trial. J Thorac Cardiovasc Surg 2011;141:338-44.

6. Okten M, Ariturk C, Gullu AU, Senay S, Toraman F, Karabulut $\mathrm{H}$, et al. Techniques for endoscopic vessel harvesting. Turkiye Klinikleri J 2015;7:54-8.

7. Desai P, Kiani S, Thiruvanthan N, Henkin S, Kurian D, Ziu $\mathrm{P}$, et al. Impact of the learning curve for endoscopic vein harvest on conduit quality and early graft patency. Ann Thorac Surg 2011;91:1385-91.

8. Kiani S, Desai PH, Thirumvalavan N, Kurian DJ, Flynn MM, Zhao X, et al. Endoscopic venous harvesting by inexperienced operators compromises venous graft remodeling. Ann Thorac Surg 2012;93:11-7.

9. Sabik JF 3rd. Understanding saphenous vein graft patency. Circulation 2011;124:273-5.

10. Deppe AC, Liakopoulos OJ, Choi YH, Slottosch I, Kuhn EW, Scherner M, et al. Endoscopic vein harvesting for coronary artery bypass grafting: A systematic review with metaanalysis of 27,789 patients. J Surg Res 2013;180:114-24.

11. Athanasiou T, Aziz O, Al-Ruzzeh S, Philippidis P, Jones C, Purkayastha $\mathrm{S}$, et al. Are wound healing disturbances and length of hospital stay reduced with minimally invasive vein harvest? A meta-analysis. Eur J Cardiothorac Surg 2004;26:1015-26.

12. Crouch JD, O'Hair DP, Keuler JP, Barragry TP, Werner $\mathrm{PH}$, Kleinman LH. Open versus endoscopic saphenous vein harvesting: Wound complications and vein quality. Ann Thorac Surg 1999;68:1513-6.

13. Rao C, Aziz O, Deeba S, Chow A, Jones C, Ni Z, et al. Is minimally invasive harvesting of the great saphenous vein for coronary artery bypass surgery a cost-effective technique? J Thorac Cardiovasc Surg 2008;135:809-15. 